\title{
PENGARUH TERAPI POSISI LATERAL KANAN TERHADAP KUALITAS TIDUR PASIEN GAGAL JANTUNG DI RSUP M DJAMIL PADANG
}

\author{
Marnila Yesni \\ Sekolah Tinggi Ilmu Kesehatan Baiturrahim Jambi \\ Email:ihyalatif28@gmail.com
}

\begin{abstract}
The heart failure disease incident rate is high in the world and Indonesia. Heart failure patients suffer from poor sleep quality. This affects the disease recovery process and increases the mortality and morbidity rates. Patients need an intervention to overcome the issue and the role of a nurse is highly needed to overcome it. The purpose of this research was to identify the effects of nursing intervention of therapy of right lateral position on the sleep quality of heart failure patients. The method used was the Quasi Experiment with the pre and post test control group consisting of 15 respondents of intervention group and 14 respondents of control group treated at RSUP M Djamil Padang, determined according to the inclusion criteria. The results of research indicated that there was a significant difference in the sleep quality of right lateral position group and the control group with the value $(p=$ value $=0,001)$. The statistics test used was the independent T test. Sleep is the necessity of human beings. By giving the intervention of therapy of right lateral position, the issue of poor sleep quality in heart failure patients may be resolved. Health care service, particularly nurses, is advised to apply this therapy as an independent nursing intervention to increase the sleep quality of heart failure patients treated at the hospital.
\end{abstract}

Keywords: therapy of right lateral position, sleep quality, heart failure

\begin{abstract}
ABSTRAK
Angka kejadian penyakit gagal jantung tinggi baik di dunia maupun Indonesia. Pasien gagal jantung mengalami kualitas tidur yang buruk. Hal tersebut mempengaruhi pada proses pemulihan penyakit dan meningkatkan angka mortalitas dan morbiditas. Pasien memerlukan intervensi untuk mengatasi hal tersebut dan peran perawat sangat dibutuhkan untuk mengatasi masalah ini. Penelitian ini bertujuan mengetahui pengaruh intervensi keperawatan terapi posisi lateral kanan terhadap kualitas tidur pasien gagal jantung. Metode yang digunakan Quasi Eksperiment dengan pre and post test control grup yang terdiri dari 15 responden kelompok intervensi dan 14 responden kelompok kontrol yang dirawat di RSUP M Djamil Padang, ditetapkan sesuai dengan kriteria inklusi. Hasil penelitian menunjukkan terdapatnya perbedaan yang signifikan selisih kualitas tidur antara kelompok posisi lateral kanan dengan kelompok kontrol dengan nilai ( $p$ value $=0,001)$. Uji statistik yang digunakan adalah uji independent $\mathrm{T}$ test. Tidur merupakan kebutuhan dasar manusia dengan pemberian intervensi terapi posisi lateral kanan dapat membantu mengatasi masalah kualitas tidur yang buruk pada pasien gagal jantung. Disarankan bagi pelayanan kesehatan terutama bagi perawat untuk menerapkan kombinasi terapi ini sebagai salah satu intervensi untuk meningkatkan kualitas tidur pada pasien gagal jantung yang dirawat di rumah sakit.
\end{abstract}

Kata kunci: terapi posisi lateral kanan, kualitas tidur, gagal jantung 


\section{PENDAHULUAN}

Gagal jantung merupakan kumpulan dari penyakit yang disebabkan karena berkurangnya fungsi dari jantung untuk memompakan darah keseluruh jaringan secara maksimal karena mengalami gangguan fungsi dan struktur dari jantung (Setiaty, 2014). Resiko gagal jantung setiap tahunnya semakin mengalami peningkatan, menurut data WHO tahun 2013 didapatkan 17,3 juta orang meninggal dikarenakan oleh gangguan kardiovaskuler di tahun 2008. Kejadian gagal jantung terus meningkat dengan populasi yang menua, hal ini diproyeksikan bahwa prevalensi gagal jantung akan meningkat sebesar $23 \%$ tiap tahunnya dari $2,42 \%$ menjadi $2,97 \%$ tahun 2030 (Bluemke, 2014). Dari hasil penelitian Santos (2012) menemukan bahwa lima gejala yang sering dialami oleh pasien gagal jantung yaitu dispnea $(82,2 \%)$, kelelahan $(84,9 \%)$, mulut kering $(74,1 \%)$, mengantuk di siang hari $(67,9 \%)$ dan sulit untuk tidur $(64,2 \%)$.

Kualitas tidur merupakan suatu keadaan seseorang dapat kemudahan untuk memulai tertidur (latensi tidur) dan untuk mempertahankan tidur, komponen dari kualitas tidur dapat digambarkan dengan lama waktu tidur dan keluhan - keluhan yang dirasakan diwaktu tidur dan saat bangun tidur (Potter \& Perry, 2010). Berdasarkan hasil penelitian Shiow (2012) dari 101 pasien gagal jantung $81 \%$ memiliki kualitas tidur yang buruk, 32 pasien melaporkan tidur kurang dari 5 jam dan 25 pasien melaporkan tidur kurang dari 6 jam serta 14 pasien membutuhkan 31 - 60 menit untuk jatuh tertidur, 32 pasien tidak dapat tertidur dalam waktu 30 menit lebih dari 3 kali seminggu. Menurut Santos (2012), dari 400 pasien gagal jantung yang diteliti $68,5 \%$ nya memiliki kualitas tidur yang buruk, dimana komponen kualitas tidur yang tertinggi terdapat pada durasi dan latensi tidur yakni mean durasi tidur harian 6 jam dan mean latensi tidur 42 menit, penyebab buruknya kualitas tidur adalah $80,3 \%$ terbangun tengah malam dan tidak mampu tertidur kembali dalam waktu 30 menit 77,7 \%. Hasil penelitian Matsuka, 2016 memperoleh tingginya kualitas tidur yang buruk lebih di dominankan pada durasi dan latensi tidur yaitu 48,2\% latensi tidur lebih dari 30 menit dan 59,3\% durasi tidur yang pendek. Norra (2012) juga mengemukakan dari komponen kualitas tidur latensi tidur yang panjang dan durasi tidur yang memendek menunjukkan efek yang lebih besar bagi pasien gagal jantung dibanding pasien non gagal jantung. Menurut Amin (2016) latensi tidur yang normal adalah kurang dari 30 menit, durasi tidur normal adalah 6 7 jam dan tidur yang efisien adalah lebih dari $85 \%$. Latensi tidur yang panjang dapat mempersingkat durasi tidur dan berpengaruh terhadap efisiennya tidur seseorang (Amin, 2016).

Tidur merupakan suatu kegiatan yang sangat dibutuhkan oleh tubuh dan merupakan suatu kebutuhan dasar bagi manusia, dimana pada saat istirahat dan tidur tubuh melakukan pemulihan dan mengumpulkan stamina kembali dari aktivitas yang telah dilakukan selama 
terjaga sehingga dapat kembali ke kondisi yang lebih optimal (Guyton \& Hall, 2014). Selama tidur tingkat metabolisme menurun dan tubuh merevitalisasi fungsi fisik dan psikologis (Zisapel, 2011). Seseorang apabila kurang tidur dapat mengakibatkan menurunnya konsentrasi, emosi yang tidak stabil, denyut jantung yang tidak teratur, gangguan fungsi imunitas dan perubahan metabolisme (Lauderdale, 2006).

Penderita gagal jantung yang mengalami kualitas tidur yang buruk akan semakin memperparah kondisi penderitanya. Jantung yang sudah mengalami gangguan jika disertai dengan kualitas tidur yang buruk akan menyebabkan kerja jantung semakin berat, proses revitalisasi fisik dan psikologis menurun sehingga memperparah penyakit yang diderita dan tentu akan memperpanjang hari rawatan pada pasien dan berakhir dengan bertambahnya angka morbiditas. Oleh karena itu dibutuhkan intervensi dalam penanganannya, apalagi komponen kualitas tidur yang sering dialami penderita gagal jantung adalah latensi tidur yang panjang atau kesulitan untuk memulai tidur, berlanjut durasi tidur yang pendek dan berefek tidur yang tidak efisien, dimana dalam hal ini sangat dibutuhkan peran perawat sebagai pemberi asuhan keperawatan terutama dalam pemberian kenyamanan bagi pasien menjelang tidur.

Menurut Dochterman \& Bulechec Nursing Intervention Clasification dalam memberi asuhan keperawatan salah satu intervensi pilihan yaitu positioning (tindakan pemberian posisi tubuh untuk meningkatkan kesejahteraan dan kenyamanan pasien). Posisi dalam tidur pada pasien gagal jantung juga sangat penting, menurut hasil penelitian Febtrina (2014) posisi istirahat lateral kanan merupakan salah satu intervensi keperawatan yang dapat digunakan untuk mempertahankan status hemodinamik (denyut jantung, laju pernafasan, tekanan darah diastolik, tekanan darah sistolik, saturasi oksigen dan tekanan darah arteri rata-rata) pasien gagal jantung dan menurut hasil penelitiannya ini juga didapat bahwa pasien gagal jantung pada posisi istirahat lateral kanan merasakan kenyamanan tingkat sedang. Selain itu posisi lateral kanan juga dapat meningkatkan saraf vagal (parasimpatis) dan menurunkan saraf simpatik (Gordon, 2011;Jain, 2013). Pada saat miring kekanan akan meningkatkan saraf vagal ( parasimpatik).

Pasien gagal jantung mengalami beban kerja jantung yang berat dengan pemberian posisi lateral kanan dapat mengurangi beban kerja jantung pada pasien gagal jantung dan status hemodinamik (denyut jantung, laju pernafasan, tekanan darah sistolik, tekanan darah diastolik, saturasi oksigen dan tekanan arteri rata-rata) dapat dipertahankan, selain itu dengan posisi lateral kanan juga dapat mengurangi sleep apnea yang sering dialami pasien gagal jantung dimana mengganggu kualitas tidur.

\section{METODE PENELITIAN}

Penelitian ini merupakan penelitian kuantitatif dengan desain 
penelitian quasi eksperimen dengan pre and post test control group, yaitu melakukan intervensi kepada subjek penelitian untuk melihat efek dari intervensi tersebut dengan menggunakan kelompok kontrol. Intervensi dilakukan malam menjelang pasien tidur dilakukan selama 3 hari, penelitian ini dilakukan di ruang rawat inap penyakit dalam dan bangsal jantung RSUP M Djamil. Sampel terdiri dari 15 responden kelompok intervensi dan 14 responden kelompok kontrol yang dirawat di RSUP M Djamil Padang. Kriteria inklusi dalam penelitian ini adalah beragama islam, pasien gagal jantung derajat I dan II saat pengkajian oleh peneliti, pasien gagal jantung yang mengalami kualitas tidur yang buruk dengan skor $0-33 \mathrm{~mm}$, tidak ada distritmia yang mengancam (VT,SVT) yang dilihat pada dokumentasi rekam medik responden, mampu membaca dan menulis.

$$
\text { Pengambilan data dilakukan }
$$

pada tanggal 25 Oktober - 19 November 2017. Instrumen penelitian yang digunakan untuk menilai Kualitas tidur menggunakan kuesioner RCSQ (Richards campbell sleep questionnaire) berisikan 5 item pertanyaan diantaranya: Skala mengevaluasi persepsi kedalam tidur, latensi tidur, jumlah terbangun, waktu yang dihabiskan terjaga dan kualitas tidur keseluruhan. Skoring jawaban dari masing masing komponen ini diberi skor analog visual dari 0 sampai $100 \mathrm{~mm}$. Skore yang dipersepsikan oleh responden dari kelima item tersebut dijumlahkan dan total penjumlahan di bagi lima. Menilai tingkat kecemasan dengan menggunakan

\section{ZSAS (Zung Self Rating Anxiety} Scale)

\section{HASIL DAN PEMBAHASAN}

Hasil analisis univariat dalam penelitian ini didapatkan ratarata usia responden pada kelompok intervensi 59,21 tahun dengan standar deviasi 6,06 tahun, usia termuda 50 tahun dan tertinggi adalah 68 tahun. Berdasarkan hasil estimasi interval dapat disimpulkan bahwa $95 \%$ diyakini rerata usia pada kelompok intervensi berkisar antara 55,71 - 62,72 tahun. Rata-rata kualitas tidur pada pasien penyakit gagal jantung terurai pada tabel dibawah ini.

Tabel 1 Rata-Rata Kualitas Tidur Pada Responden Gagal Jantung di RSUP M Djamil Padang $(n=29)$

\begin{tabular}{lll}
\hline Variabel & Mean \pm SD & $95 \%$ CI \\
& & \\
\hline Kelompok & & \\
Kontrol & & \\
Pre test & $31,04 \pm 1,60$ & $30,11-31,97$ \\
Post test & $32,23 \pm 2,12$ & $31,03-33,45$ \\
Kelompok & & \\
Intervensi & & \\
Pre test & $31,60 \pm 1,55$ & $30,74-32,46$ \\
Post test & $50,69 \pm 5,14$ & $47,84-53,54$ \\
\hline
\end{tabular}

Hasil analisis pada tabel 1 didapatkan bahwa rata-rata kualitas tidur pada kelompok kontrol sebelum intervensi yaitu 31,04 dengan standar deviasi 1,606 dan rata-rata kualitas tidur setelah intervensi yaitu 32,23 dengan standar deviasi 2,12. Sementara itu rata-rata kualitas tidur pada kelompok intervensi sebelum intervensi yaitu 31,60 dengan standar deviasi 1,55 dan rata-rata kualitas 
tidur setelah intervensi yaitu 50,69 dengan standar deviasi 5,14.

Secara fisiologis, kontrol kardiovaskular dihasilkan melalui keseimbangan pengaturan antara sistem saraf simpatis dan parasimpatis. Mekanisme ini melibatkan refleks medular dan area pusat kontrol otonom. Aktivasi refleks medular distimulasi oleh baroreseptor, cardiac receptors dan kemoreseptor. Mekanisme ini berkaitan erat dengan tekanan darah dan HR. Sedangkan pada pasien penyakit gagal jantung juga mengalami gangguan vaskular pada jantung, sehingga mengakibatkan peningkatan tekanan darah dan HR. Hal ini sangat berkaitan dengan aktivasi dari baroreseptor dan kemoreseptor yang akhirnya meningkatkan aktivasi saraf simpatis. Hal ini mengakibatkan pengaturan kontrol saraf simpatis dan parasimpatis yang tidak seimbang, sehingga berakibat pada disregulasi kontrol otonom. Studi pemantauan otonom menjelaskan kekacauan progresif siklus bangun dan tidur ditandai oleh penurunan drastis total waktu tidur dan hilangnya fisologis tidur (Calandra-Buonaura et al, 2016)

Perbedaan Kualitas Tidur Sebelum dan Setelah Intervensi Terapi Posisi Lateral Kanan pada Pasien Penyakit Gagal Jantung.

Tabel 2Analisis Perbedaan Kualitas Tidur Sebelum dan Setelah Intervensi Terapi Posisi Lateral Kanan pada Pasien Penyakit Gagal Jantung di RSUP M Djamil Padang (n=29)

Variabel Mean \pm SD $\quad$ SE $p$ value

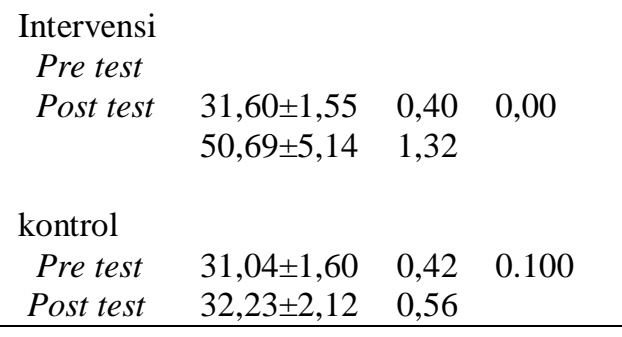

Hasil analisis pada tabel.2 menunjukkan terdapat perbedaan yang bermakna antara kualitas tidur sebelum dan setelah intervensi kombinasi terapi posisi lateral kanan dan murottal Qur'an diberikan dengan $p$ value $0,00(p<0,001, \alpha$ $0,05)$. Sedangkan pada kelompok kontrol hasil analisis menunjukkan tidak terdapat perbedaan yang bermakna antara kualitas tidur sebelum dan setelah intervensi kelompok kontrol dengan $p$ value 0,10

Perbedaan Selisih kualitas tidur Antara Kelompok Kontrol dan Kelompok Intervensi.

Tabel .3 Analisis Perbedaan Selisih Kualitas Tidur Antara Kelompok Kontrol dan Kelompok Intervensi responden gagal jantung di RSUP M Djamil Padang (n=29)

\begin{tabular}{|c|c|c|c|c|}
\hline $\begin{array}{l}\text { Selisih } \\
\text { kualitas } \\
\text { tidur }\end{array}$ & Mean & $\begin{array}{l}\text { Perbeda } \\
\text { an } \\
\text { mean }\end{array}$ & $\begin{array}{l}95 \% \\
\text { CI }\end{array}$ & $\begin{array}{l}p \\
\text { value }\end{array}$ \\
\hline kontrol & 1,19 & \multirow{3}{*}{$-17,9$} & & \multirow{3}{*}{0,001} \\
\hline & & & 20,31 & \\
\hline intervensi & 19,09 & & 14,60 & \\
\hline
\end{tabular}

Hasil analisis pada tabel.3 menunjukan nilai $p$ value $0,001 \mathrm{Hal}$ ini menunjukan terdapat perbedaan yang bermakna selisih kualitas tidur sebelum dan setelah intervensi antara 
kelompok kontrol dengan kelompok intervensi $(p<0,001, \alpha 0,05)$.

\section{Pengaruh terapi posisi lateral kanan Terhadap kualitas tidur Pasien Penyakit gagal Jantung}

Berdasarkan analisis statistik menggunakan uji beda dua mean yaitu Paired T-test diperoleh hasil rerata perbedaan kualitas tidur sebelum dan setelah intervensi pada kelompok kontrol yaitu 1,19 dengan dan $p$ value $=0,100 \quad(p$ value $>$ $0,05)$. Sehingga dapat dikatakan tidak terdapat perbedaan yang signifikan antara kualitas tidur sebelum dan setelah intervensi pada kelompok yang tidak melakukan terapi posisi lateral kanan. Sedangkan hasil yang berbeda ditemukan pada kelompok intervensi, hasil menunjukan terdapat perbedaan yang signifikan antara kualitas tidur sebelum dilakukan terapi posisi lateral kanan dengan kualitas tidur setelah dilakukan terapi pada pasien penyakit gagal jantung dengan rerata perbedaan kualitas tidur sebelum dan setelah dilakukan terapi posisi lateral kanan yaitu 19,09 dan $p$ value = $0,000$ ( $p$ value $<0,05)$.

Hasil yang ditemukan dalam penelitian ini menunjukkan tidak terdapat peningkatan kualitas tidur yang signifikan pada pasien yang tidak melakukan terapi posisi lateral kanan. $(p$ value $=0,10)$. Dalam penelitian ini pada kelompok kontrol diberikan intervensi posisi yang diinginkan responden ketika akan tidur, dalam proses pengambilan data dari kelompok kontrol ini > 50\% responden memilih posisi tidur telentang ketika akan tidur dan sisanya memilih posisi lateral kiri dan kanan. Sesuai dengan penelitian Ozeke et al (2012) Pada masa anak anak lebih nyaman tidur pada posisi rawan (tengkurap) namun ketika sudah dewasa lebih sering memilih posisi telentang dan posisi lateral. Sejalan dengan penelitian Eiseman et al (2012) bahwa laki - laki dewasa lebih sering tidur dalam posisi telentang dan dominan pilihan posisi telentang meningkat seiring bertambahnya usia.

Hal yang berbeda ditemukan pada pasien penyakit gagal jantung yang melakukan terapi posisi lateral kanan selama 3 hari (Setiap menjelang tidur selama 30 menit pemberian posisi lateral kanan), rerata perbedaan kualitas tidur sebelum dan setelah kombinasi terapi posisi lateral kanan dan murottal qur'an yaitu 19,09 dan $p$ value = 0,000 ( $p$ value < 0,05). Hal ini menunjukan peningkatan yang signifikan kualitas tidur pada pasien penyakit gagal jantung yang diberi intervensi

Pemberian posisi lateral kanan selama 30 menit menjelang tidur memberi kenyamanan secara fisik pada pasien gagal jantung. Menurut Chen \& Kuo,1997; Sharad J, 2013, menurut dari kedua penelitian ini beberapa mekanisme yang mendorong aktifitas vagus saat seseorang berbaring kearah sebelah kanan yaitu ((1) SA node menerima persarafan utama melalui persarafan vagus sebelah kanan, saraf vagus sebelah kanan pada leher akan terstimulasi oleh masase periodik dari pulsasi arteri karotis pada posisi istirahat sebelah kanan, (2) ketika berbaring sebelah kanan akan 
menguntungkan terhadap posisi anatomi atrium sebelah kanan karena menyebabkan venus return menurun dari vena kava superior dan inferior, (3) Gravitasi dapat meningkatkan beban kerja jantung ketika berbaring kearah kiri sedangkan jika berbaring ke arah kanan akan meningkatkan aktivitas vagal (saraf parasimpatis), (4) pada posisi istirahat lateral kanan akan mencegah Obstruksi saluran nafas daerah faring akibat pendorongan lidah dan palatum kebelakang yang dapat menyebabkan oklusi nasofaring dan orofaring pada saat pasien tidur, sehingga pasien akan merasa nyaman ketika tidur di posisi ini. Penelitian ini sejalan dengan penelitian Fujita et al cit Ozede (2012) pada pasien gagal jantung pada saat tidur 2 kali lebih lama tidur pada posisi lateral kanan dibandingkan dengan posisi tidur supine hal ini dikarenakan merasa lebih nyaman diposisi ini

Hal ini sesuai dengan Wilkinson (2012) bahwa pemberian intervensi untuk peningkatan tidur seseorang dibutuhkan pemenuhan faktor fisik maupun psikologis. Ketika seseorang akan memulai tidur agar mudah jatuh tertidur diawali dengan kondisi fisik seperti denyut jantung, frekuensi pernafasaan serta tekanan darah yang lambat dan stabil (Guyton \& Hall, 2014; Zisapel, 2011).

\section{SIMPULAN}

Penelitian ini memberikan gambaran pengaruh terapi posisi lateral kanan terhadap kualitas tidur pasien gagal jantung.intervensi ini dapat diterapkan dirumah sakit sebagai salah satu intervensi untuk membantu peningkatan kualitas tidur.

\section{SARAN}

Diharapkan untuk peneliti selanjutnya untuk meneliti dengan kombinasi terapi lain atau menambah variabel lain.

\section{DAFTAR PUSTAKA}

1. Akintunde, O. (2013). Snoring and Risk for Obstructive Sleep Apnea among Nigerians with Heart Failure: Prevalence and Clinical Correlates, 14(1). http://doi.org/10.4103/1995705X.107115

2. Asai T, Kaneita Y, Uchiyama $\mathrm{M}$, Takemura S, Asai S, Yokoyama E, Miyake T, Harano S, Suzuki K, Ibuka E, Kaneko A, Tsutsui T, Ohida T. Epidemiological study of the relationship between sleep disturbances and somatic and psychological complaints among the Japanese general population. Sleep Biol Rhythms 2006;4:55-62

3. Alhouseini, A. M. R. A., Alshaikhli, I. F., Wahab, A., \& Alarabi, K. (2015). Stress Assessment While Listening To Quran Recitation. http://doi.org/10.1109/CASH. 2014.14

4. Amin, N., Allebrandt, K. V, Spek, A. Van Der, Müllermyhsok, B., Hek, K., Tederlaving, M., ... Roenneberg, T. (2016). Genetic variants in RBFOX3 are associated with 
sleep latency, (August 2015), 1-8.

http://doi.org/10.1038/ejhg.20 16.31

5. Babaii, A., Abbasinia, M., Hejazi, S. F., Reza, S., \& Tabaei, S. (2015). The Effect of Listening to the Voice of Quran on Anxiety before Cardiac Catheterization: A Randomized Controlled Trial, 2(2), 8-14.

6. Black, J.M. \& Hawks, J.H.2009.Medical Surgical Nursing Clinical Management for Positive Outcomes.St. Louis : Elsevier

7. Bluemke, D. A., Butler, J., Frcp, C., Pham, M., Piña, I. L., \& Justin, G. (2014). Forecasting the Impact of Heart Failure in the United States:, 6(3), 606-619. http://doi.org/10.1161/HHF.0 b013e318291329a.Forecastin $\mathrm{g}$

8. Calandra-buonaura, G., Provini, F., Guaraldi, P., Plazzi, G., \& Cortelli, P. (2015). Running Title: Cardiovascular

dysautonomia and sleep disorders. Sleep Medicine Reviews.

http://doi.org/10.1016/j.smrv. 2015.05.005

9. Dahlan, M. Sopiyudin. (2011). Statistik Untuk Kedokteran Dan Kesehatan Ed. 5. Jakarta : Salemba Medika.

10. Dharma, Kusuma Kelana (2011), Metodologi Penelitian Keperawatan : Panduan Melaksanakan dan Menerapkan

Hasil
Penelitian, Jakarta, Trans InfoMedia.

11. Dahlan, M. S. (2009). Besar Sampel dan Cara Pengambilan Sampel Dalam Penelitian Kedokteran dan Kesehatan . Jakarta: Salemba Medika .

12. Dahlan, M. S. (2009). Langkah-langkah Membuat Proposal Penelitian Bidang Kedokteran dan Kesehatan . Jakarta: Sagung Seto.

13. Davis, M., Eshelman, E.R. \& McKay, M. (2008). The Relaxation \& Stress Reduction Workbook. Oakland, CA. New Harbinger.

14. Deursen, V. M. Van, Urso, R., Laroche, C., Damman, K., Dahlström, U., Tavazzi, L., ... Voors, A. A. (n.d.). Comorbidities in patients with heart failure: an analysis of the European Heart Failure Pilot Survey. doi:10.1002/ejhf.30

15. Easton, K., Coventry, P., Econ, M. A., Lovell, K., Hons, B. A., Carter, L., \& Deaton, C. (2015). Prevalence and Measurement of Anxiety in Samples of Patients With Heart Failure, O(0), 1-13. http://doi.org/10.1097/JCN.0 000000000000265

16. Elzaky, J. (2011). Mukjizat Kesehatan Ibadah. Jakarta: Penerbit Zaman

17. Eisenberg, S. A. (2010). The influences of Anxiety, Coping , and Social Support on Physical Functioning among heart Failure Patients by a 
Thesis Presented to the faculty of the usc Graduate School in Partial Fulfillment of the Requirements for the Degree Master of arts ( psychology ) august 2010 copyright 2010, (august).

18. Erickson VS, Westlake CA, Dracup KA, Woo MA, Hage A. Sleep disturbance symptoms in patients with heart failure. AACN Clin Issues 2003;14:477-487.

19. Jakovljevic, D. G., Papakonstantinou, L., Blamire, A. M., Macgowan, G. A., Taylor, R., Hollingsworth, K. G., \& Trenell, M. I. (2014). Ventricular Structure and Function Effect of Physical Activity on Age-Related Changes in Cardiac Function and Performance in Women. http://doi.org/10.1161/circima ging.114.002086

20. Javadi, N., Darvishpour, A., Mehrdad, N., \& Lakeh, N. M. (2014). Survey of Sleep Status and its Related Factors among Hospitalized Patients with Heart Failure, 10(1), 918.

21. Mustamir Pedak. (2009). Metode Supernol Menaklukkan Stres.Jakarta: Hikmah Publishing House

22. Guyton A.C. and J.E. Hall 2014. Buku Ajar Fisiologi Kedokteran. Edisi 12. Jakarta: EGC.
23. Goodman dan Gilman's. (2012). Dasar Farmakologi Terapi. Diterjemahkan oleh Tim Ahli Bahasa Sekolah Farmasi ITB. Edisi 10. Jakarta: EGC. Hal.379.

24. Paneni,F. MD, PHD, a,b Candela Diaz Cañestro, MSC, a Peter Libby, MD, PHD,c Thomas F. Lüscher, MD,a,b Giovanni G. Camici, PHD (2017). The Aging Cardiovascular System, 69(15). http://doi.org/10.1016/j.jacc.2 017.01.064

25. Potter, P. A. Perry, Anne Griffin. (Eds). 2010. Buku Ajar Fundamental Keperawatan: Konsep, Proses, dan Praktek Edisi 5 Volume 2. Jakarta : EGC

26. Reid KJ, Martinovich Z, Finkel S, Statsinger J, Golden R, Harter K, Zee PC.(2006) Sleep: a marker of physical and mental health in the elderly. Am J Geriatr Psychiatry; $14: 860-866$

27. Wang TJ, Lee SC, Tsay SL, Tung HH. Factors influencing heart failure patients> sleep quality. J Adv Nurs 2010;66:1730-1740. doi: $\quad 10.1111 /$ j.13652648.2010.05342.x.

28. Wilkinson.J \& Ahern .N.R, (2012) Buku Saku Diagnosa keperawatan, Edisi 9 Jakarta : Buku Kedokteran EGC. 